\section{UK computer research to switch to Europe, says policy review}

\section{London}

THE gloomy predictions of Britain's information technology community were confirmed last week when the government finally rejected proposals for a $£ 1,000 \mathrm{mil}$ lion, five-year research programme to succeed the Alvey project, which is nearing completion. The bulk of research in information technology will instead be done through the second phase of the European Community's $£ 1,100$ million ESPRIT programme, to which Britain has contributed $£ 200$ million. A modest national initiative is proposed to complement ESPRIT, for which the Department of Trade and Industry (DTI) will provide $£ 29$ million over the next three years, with the Science and Engineering Research Council (SERC) devoting $£ 55$ million over five years.

The Alvey programme was funded by $£ 200$ million of public money (through the Ministry of Defence, DTI and SERC), with industry providing $£ 150$ million. More than 200 industrial projects received support. In November 1986, a committee under Sir Austin Bide, former chairman of the Glaxo pharmaceutical group, recommended a continuation of the programme focusing largely on application of new technologies, with the government contribution increasing to $£ 425$ million.

The government's response to these proposals is contained in a white paper (policy document) published last week*, marking the completion of an extensive internal review of the DTI, instigated by the new secretary of state, Lord Young.

The white paper concedes that "the Alvey Programme has provided a good focus for the IT [information technology] research community". Researchers complain that not only is the proposed level of funding of the new programme inadequate for Britain to remain competitive, but the enforced switch from well-established domestic relationships between industrial and academic partners to a European programme, through the infamous Brussels bureaucracy, will result in damaging discontinuity.

The white paper signals a shift towards support for longer-term collaborative research and away from 'near-market' initiatives, which the government believes industry should itself finance. In line with stated government policy, the DTI will seek to encourage more collaboration between the industrial and academic sectors and between individual companies. Collaboration will be achieved, says the white paper, through European Community programmes and domestic initiatives such as the LINK programme (which was announced more than a year ago but which has still not yet seen the light of day). ution to a national programme of research into high-temperature superconductivity: a total of $£ 8$ million to be made available over three years, but there is no news yet about how or to whom.

The review has little direct effect on the activities of the British National Space Centre, still part of the DTI despite its wish for autonomy. The white paper reiterates that no increase is proposed to the DTI's present contribution of $£ 70$ million to the space budget. But space minister Kenneth Clarke has been canvassing in-
Also announced is the DTI's contrib-

\section{San Francisco}

THE world's first computerized data bank of 'DNA fingerprint' information on convicted criminals is now being planned. The California attorney general's office has begun studies to determine the best methods for collecting and storing data, and expects the database - which will be used to identify and prosecute repeat offenders - to be on line in 3-5 years. But questions over how the data will stand up in court may delay the database's applicability.

State forensic scientists are investigating several methods for analysing samples to be entered into the database, and they are unlikely to select the method developed by Alec Jeffreys of the University of Leicester (see Nature 317, 818; 1985), which has been used successfully in immigration and forensic cases in the United Kingdom. The Jeffreys method uses probes for hypervariable minisatellite DNA, and produces a complex pattern of bands that may be difficult to store in a database and compare reliably to newly run samples. Data storage and comparison will be simpler with the single-locus or dot-blot approaches, according to Steve Helsley, chief of forensic services in the California attorney general's office.

The dot-blot technique is considered less labour-intensive, works on the degraded DNA of forensic samples and requires only 10 nanograms of DNA, an amount obtainable from a single hair root. The 0.1-1 micrograms of intact DNA necessary for single-locus analysis is obtainable only in 60 per cent of the cases, according to John Winkler, president of Lifecodes, a New York company that specializes in DNA analysis.

Henry Erlich, director of human dustry on its priorities for space research and the status of the space centre is being reappraised in order to allow closer links with the industrial community. An announcement on the future role of the space centre is expected before a replacement is found for the director-general, Jack Leeming, who retires at the end of next month.

To strengthen links between business and education, the government proposes that 10 per cent of teachers should each year "have the opportunity to gain some personal experience of the world of business". An extra $£ 5$ million will support advanced technology in schools and further education colleges, and The Teaching Company Scheme, which enables graduates to undertake projects in companies, will be expanded.

Simon Hadlington

${ }^{*} D T I$ - the department for Enterprise. HMSO, $\$ 5.00$.

\title{
DNA fingerprinting database to finger criminals
}

genetics at Cetus Corporation, which developed the polymerase chain reaction and the dot-blot technique, says the company will soon have enough probes for informative polymorphic sites to offer identification of an individual with less than a one-in-a-million chance of a false positive result.

Ideally, the DNA samples for the database would be analysed in several different ways, says Helsley, because the technique used in a particular case may be dictated by the amount and condition of the DNA available for analysis.

Whatever method is chosen by California, defendants should have a source for an independent alternate test. Singlelocus analysis is performed by both Lifecodes and Cellmark, a Maryland-based division of Imperial Chemical Industries (the British company that owns the Jeffreys probes), and Cetus plans to market a kit that should enable any laboratory to perform the simpler, dot-blot analysis.

Although DNA data have been used as evidence in criminal cases in at least five states, no case based on DNA evidence has resulted in a conviction, says Helsley. State Attorney General John Van de Kamp is not ready to have DNA go to court in California, because he doubts whether DNA forensic analysis has been sufficiently validated to pass the KellyFrye requirements, which state that there must be scientific consensus on the reliability of a forensic technique before the evidence is admissible in court.

The first entries into the database will come from the more than 5,000 blood and saliva samples collected from convicted sex offenders in California in the past five years.

Marcia Barinaga 